\title{
Business Strategy and Development
}

\section{What is hindering change? Anticipating the barriers to the adoption of enzyme-based textile processing in a developing country}

\begin{tabular}{|r|l|}
\hline Journal: & Business Strategy and Development \\
\hline Manuscript ID & BSD-19-0013.R1 \\
\hline Wiley - Manuscript type: & Research Article \\
\hline Keywords: & $\begin{array}{l}\text { Enzyme, Textile, Developing Countries, Organic Processing, Sustainable } \\
\text { Environment, Green Manufacturing }\end{array}$ \\
\hline
\end{tabular}

Mahfuzur Rahman (corresponding author)

marahman@lincoln.ac.uk

Lincoln International Business School

University of Lincoln, UK

Md Morsaline Billah

mbillah@lincoln.ac.uk

Lincoln International Business School

University of Lincoln, UK

Dieu Hack-Polay

dhackpolay@lincoln.ac.uk

Lincoln International Business School

University of Lincoln, UK

Acknowledgement: The work is funded by Commonwealth Rutherford Fellowship 


\title{
What is hindering change? Anticipating the barriers to the adoption of enzyme-based textile processing in a developing country
}

\begin{abstract}
The study aimed to examine the barriers to embracing enzymatic processing in the garment industry in a developing country. We used the case of Bangladesh, which has the largest garment sector in the world. The research used semi-structured interviews with ten high profile figures in the industry, comprising scientists, manufacturers, enzyme traders and policymakers. We found economic, sociocultural, informational and policy-related barriers to the adoption of enzymatic processing. Attending to each element would benefit manufacturers primarily; this will help identify its strengths and weaknesses to ensure the effective implementation of enzymatic textile processing to obtain optimum results. The study also found that manufacturers' desire to help improve environmental performance is a factor which could motivate them in adopting green manufacturing innovation. It is expected that regulatory frameworks that encourage innovation - particularly from high social responsiveness and compliances as well as economic and financial incentives - would motivate manufacturers to develop sustainable environmental management strategies that enhance their ability to compete in global markets.
\end{abstract}

\section{INTRODUCTION}

The textile industry is one of the oldest industries and remains a major industrial sector worldwide. In the past few decades, it has experienced major growth owing to high profitability, increased textile consumption and fashion trends. According to the World Trade Statistical Review, the worldwide textile export and apparel were $\$ 296.1$ billion and $\$ 454.5$ billion respectively in 2017 , which increased by $4.2 \%$ and $2.8 \%$ on the previous year (WTO, 2018). In the textile wet processing, natural or man-made (synthetic) fibers serve as the raw material in the form of yarn, fabric and garments. Sequential treatment of fabric requires substantial quantity of energy, water, different types of chemicals and auxiliaries for finished products. This discharges considerable amount of polluted effluent; effluent comprises of unfixed dyes and chemical auxiliaries which are toxic to human health and ecosystem. The textile industry uses a large variety of toxic chemicals in manufacturing; approximately $25 \%$ of the chemicals manufactured globally are applied in the textile industry (Greer et al. 2015; 
Senthil Kumar and Gunasundari, 2018). The important volume of effluent necessitates a separate treatment process before it could be disposed of into water bodies. An estimate shows that china is responsible for 3 billion tons of annual waste water discharge from the textile industry, while $54 \%$ of the world textile production takes place in one country [Bangladesh] (Greer et al. 2015).

To circumvent these undesirable circumstances, textile industries are required to adopt innovative approaches or modify existing processes and practices and incorporate environmentally-friendly technologies. A greener concept has therefore been introduced for the production of eco-friendly textiles based on chemical-free, low impact and natural dyeing and bio-processing techniques, which allow the sustainable production of fabric (Anastas and Warner 1998). The environmental impacts can be reduced with increased uses of eco-friendly or organic fibers. Organic plant-based fibers, wool and silk are increasingly used as ecofriendly fibers. In addition, bio-based processing is required to replace the toxic chemical to curb further alienation of public health and environmental issues. Industrial sustainability can, thus, be addressed with the optimization of water and energy uses, replacement of chemicals, modification of existing processes and equipment, etc. (Senthil Kumar and Gunasundari, 2018). In this paper we seek to answer the following questions: What is the role of technology in environmental sustainability by businesses? To what extent can firms play a responsible role in tackling environmental challenges by innovating or adopting sustainable products and/or business practices (Melander, 2018; Chiarvesio, Marchi and Maria, 2015; Dangelico, 2016; Dangelico, Pujari and Pontrandolfo, 2017; Goodman, Korsunova and Halme, 2017; Hofmann, Theyel and Wood, 2012)? What are key barriers to technological implementation in the context of environmental sustainability, specifically focusing on the barriers to the adoption of enzymatic textile processing? We present and discuss the findings from the interviews with key stakeholders in the industry in Bangladesh. We opted to focus on Bangladesh because, according to Mostafa and Klepper (2017: 616), "a major impetus to its underlying economic growth was the rise in exports, fuelled by one industry-garments which currently accounts for $80 \%$ of the country's total exports". This makes Bangladesh the second largest garments exporter of the world following China (Alam, Selvanathan and Selvanathan, 2017) and therefore an excellent candidate to study barriers to the adoption of enzymatic processing in the textile industry. 


\section{LITERATURE REVIEW}

\section{Technology and the environment}

In the past few decades, society has developed greater awareness of environment issues and their impact on human health. This ranges from global warming resulting from environmental degradation, air pollution and carbon emission, etc. The impact of these happenings on climate change and people's health can be life threatening, though some scientists and politicians downplay such impacts (Shrum, Lowrey and McCarty, 2008).

Technology is gradually following the consciousness about the consequences of environmental degradation. For example, significant investment has been made in research in the areas of electric cars and solar energy in view to reduce the use of fossil fuel. In households, there is more government pressure to get people to recycle more, providing basic recycling facilities, e.g. segregated containers, etc. A number of technologies - e.g. air purifiers, air quality measurement devices, noise minimization devices including enhanced windows - have emerged to protect the health of populations exposed to toxic gases. However, such efforts, though supported by some governments, scientists and business leaders, are not yet sufficient to stop the fatal consequences of environmental degradation. In the UK, for instance, found significant correlation between air pollution due to nitrogen dioxide and children's poor cognition and health. It is argued that over 36000 people die of the effects of pollution every year. This is a significant number of fatalities for a single country; if cascaded at global level, the casualties caused by environmental degradation can be colossal. Similar conclusions were arrived at in several Asian countries emerging economies including China and India, etc., hence the need for every sphere of society to act within its capabilities to minimise the issue. The textile industry is a major source of water pollution, yet under-researched (Landrigan et al., 2018) and little understood, particularly in the Global South countries such as Bangladesh and Sri Lanka, etc. which are the main global outsourcing countries for the production of garments. In this perspective, our research is an important endeavor looking into how communities and businesses can be sensitised to use enzymatic technologies in the production of garments.

\section{Barriers to technological implementation for environmental sustainability}


A major barrier to the diffusion of technical progress appears to lie in the existence of vested interests among economic agents specialising in old technologies and who may, therefore, collude and exert political pressure on governments to impose administrative procedures, taxes, trade barriers and regulations geared at delaying or even preventing the emergence of new innovations that might destroy their rents (Olson, 1982). The duration of the delay will depend several factors: the strengths of the political institutions, technological characteristics (learning by doing and knowledge externalities) and the balance of power between innovators and incumbents. The more learning by doing and the more positive knowledge externalities on the older technology, other things being equal, the lower the frequency of new innovations (Jovanovic and Nyarko, 1994; Krusell and Rios-Rull, 1996; Aghion and Howitt, 1998).

The barriers to achieving technical potential relate to technology cost and performance. Technologies can be improved by solving scientific and technological problems; policies to overcome this category of barriers could be aimed at fostering research and development $(\mathrm{R} \& \mathrm{D})$ in the public or private sectors. In addition, because production costs typically fall as experience with a particular technology accumulates, policies that foster adoption of new technologies can, over time, produce cost reductions and performance improvements. The effect of such improvements would be to make the technologies more cost-effective and consumer-favoured, thus improving the economic and socioeconomic potentials of these technologies. Other barriers to the achievement of socioeconomic potential of textile enzyme include social and cultural constraints, and economic forces that are characterised as desirable features of markets or other institutions. In addition, the barriers related to socioeconomic potential include consumer preferences, e.g. attitudes to uncertainty of using textile enzymes by the industries of developing countries. Uncertainty arises when the application of new enzymatic technologies and cost savings supersedes the limits the adaption of new technologies; this type of reluctance in the face of dilemma is completely rational given the irreversible nature of many resource-intensive industrial investments (Hassett and Metcalf, 1993, 1995).

A significant barrier to the incorporation of enzymatic technology in the textile industry is the lack of research personnel or trained manpower. Lack of trained manpower, lack of technical assistance and professional training for technicians and lack of ability for testing largely will weaken the potential efficiency of economic measures (Andrews-Speed, 2004). Education and training are prime requirements for achieving success in any organisation. Many developing 
countries lag behind industrialised nations in the experience of enzymatic bioprocessing and greener technology because of short-term development goals. In the developing world, the lack of appropriate production technologies serve as a crucial barrier to incorporate and adapt enzymatic technology into the textile processing industries. These countries rely on import of enzymes from other countries. However, these countries need to find their own ways of producing enzymes which best suit their national conditions and appreciate development of biotechnology industries and biotechnology entrepreneurship including bio-based SMEs. However, research into industrial biotechnology especially industrial production of enzymes is still in its infancy in developing countries and has not kept pace with developed countries. Industrial biotechnology research and development programmes face technical bottlenecks, lack appropriate technical expertise and resources. Therefore, it is imperative that these countries take measures to improve their production technology and overall efficiency to maintain and sustain the supply chain in the long run.

\section{Enzymatic textile processing}

Textile processing encompasses a number of processes including production of semi-processed products like yarns, woven and knitted fabrics, synthetic raw materials and final/consumer products (carpets, home textiles, readymade garments and industrial textiles). However, the use of enzymes in the manufacturing of synthetic raw materials is beyond the scope of this investigation which examines the manufacturing and treatment of textile and clothes in mills and laundries.

The processes involved in the textile industry are complex, covering every step from fiber to finished products where enzymes have potential applications, as shown in Table 1. In textile mill operations, different types of fibers such as yarn or fabric are produced and processed into usable products. All textiles are made up of fibers that are treated in different ways to create the desired strength, durability, appearance and texture. Pre-treatment processes (desizing, scouring and bleaching) are carried out with fibers, yarns or fabrics. It enables subsequent processing of the material which needs to be prepared to accept dyes and functional chemicals. Finishing introduces special technical and functional properties to the finished fabric. On the contrary, laundry operations include the after-care of the finished garment to achieve desired outcomes. Biotechnological processes have enabled industrial uses of enzymes in both textile mill and laundry operations.

Table 1. Enzymatic applications in textile processing industry 


\begin{tabular}{|c|c|}
\hline \multicolumn{2}{|c|}{ Enzymatic Textile Processes } \\
\hline Textile Mill Operations & Laundry Operations \\
\hline $\begin{array}{l}\text { Raw Fabric Production } \\
\text { - Fiber Modification } \\
\text { Preparation } \\
\text { - Desizing } \\
\text { - Scouring } \\
\text { - Bleaching (optional) } \\
\text { Dyeing } \\
\text { - Bleach Cleanup } \\
\text { - Dyeing } \\
\text { - Rinsing } \\
\text { Finishing } \\
\text { - Softening } \\
\text { - Defibrillation }\end{array}$ & $\begin{array}{l}\text { Preparation } \\
\text { - Desizing } \\
\text { - Wax Removal } \\
\text { Garment wash } \\
\text { - Abrasion } \\
\text { - Dyeing/Finishing } \\
\text { - Softening } \\
\text { Bleach and Finishing } \\
\text { - Bleach } \\
\text { - Rinsing } \\
\text { - Softening }\end{array}$ \\
\hline
\end{tabular}

Enzymatic processes are highly diverse in textile processing. However, the processes linked to textile mill operations use enzymes in four major steps, including raw fabric production, preparation, dyeing and finishing. For raw fabric production, enzymes are used for fiber modification. The preparation phase includes desizing, scouring and sometimes bleaching in which enzymes are predominantly used. For dyeing, enzymes are used for the processes in bleach cleanup, dyeing itself and finally rinsing. In the finishing step, enzymes can play a major role in the processes linked to softening and defibrillation. Laundry operations are limited to preparation, garment wash and bleach and finishing in which enzymes are usually used.

\section{Key specific barriers to enzymatic textile processing}

There have been no direct studies purporting to identify the barriers for the adaptation of enzymatic textile processing. However, there are a number of studies (Fresner et al., 2017; Peng et al., 2015; Zuberi, Tijdink and Patel, 2017) identifying a variety of sector-specific and cross-cutting energy efficiency improvements for industry. The impact of such improvements on the environment and product quality has had benefits emanating from the significant use of enzymes in wet textile processing. It is one of the most effective alternatives to the use of hazardous chemicals and dyes in wet processing in each processing stage. It creates a toxicfree environment and produces sustainable textile material. In enzymatic processes, moderate conditions and less energy are sufficient, leading to reduction in greenhouse gas emissions from 
the power stations. The water and chemical consumption is reduced by using enzymes in every wet processing operation. The byproduct formation is minimised by the enzymes that offer nontoxic and eco-friendly environment. As adaptation of enzymatic technology into textile processing offers significant improvement in energy efficiency, we have considered the studies related to energy efficiency measures as a guideline to identify the barriers in these industries in developing countries. Significant numbers of energy efficiency measures which are costeffective are not always considered by industry. Several studies (Fresner et al., 2017; Peng et al., 2015; Zuberi, Tijdink and Patel, 2017) have relatively different classification for various barriers. Different studies have varying ways of categorising the barriers; yet, in general, there is a significant overlap in those categorisations. In other words, the barriers classified under one classification can also for the most part be classified by other types of categorisations.

\section{METHODOLOGY}

We undertook interviews with 10 experts in the field of enzyme processing, using semistructured interviews, to come to an understanding of the perceived scientific and social benefits and issues relating to enzymatic processing and reasons why some stakeholders may resist the adoption of this new technology. We selected the participants using a convenience sample. This sampling strategy was adopted because it offered the flexibility to diversify our participants to capture various aspects of the technical and socio-economic issues associated with enzymatic processing. The choice of convenience sampling is associated with the fact that the authors intended to examine the experience of stakeholders who have extensive knowledge and connection with enzyme processing; however, the specialist nature of the field of the study and its novelty meant that convenience sampling was the most effective way of reaching desired participants who met our selection criteria. The main criteria for selection was to have been involved in the industry either as a scientist, manufacturer, or trader for over one year. One year was thought to be a benchmark to establish that the participants have ample experience of the technology or the local Bangladeshi context to be able to elaborate on their perception of the opportunities and barriers for the use of enzymatic technological processing. The participants interviewed included: 2 scientists/researchers, 2 manufacturing companies managers, 4 garments (users), 1 garment exporter and 1 chemical importer.

Manual analysis was undertaken given the small sample. The analysis was thematic and aimed to make sense of participants' responses. The small number of interviews meant that manual analysis was more effective in terms of time and the ability to return to the transcripts for 
greater scrutiny. We first reviewed the interview notes to start identifying possible threads that would help the axial coding process. We then generated initial codes; we subsequently developed categories which were grouped into final themes that formed the basis for the analysis and discussion. We present and discuss the data in the next section.

\section{FINDINGS AND PRELIMINARY DISCUSSION}

The examination of the interview data revealed significant barriers to adopting enzymatic technological processing in Bangladesh. While there are significant environmental benefits for a move to enzymatic processing, the thematic analysis has enabled the researchers to group those barriers as follows: economic \& trade, administrative, technological, socio-cultural \& behaviourial, informational, and environmental barriers. These are elaborated below with the support of the participants' quotes.

\section{Economic barriers}

The economic barriers to the adoption of enzymatic processing were unanimously recognised by our participants. Even the scientists involved in developing the technology and the products accepted that in the current context, cost is a significant deterrent for manufacturing firms in the garment industry. They pointed out that:

“Competitiveness of developing countries' textile and garment industry lies mainly in their cheaper cost and price, which they want to retain in any circumstances" (Participant A, Scientist).

"There's always huge custom duty and import tax. Custom clearance is very bureaucratic, complicated, lengthy and corrupt. In most cases, enzymes lose their properties during this process" (Participant B, Managing Director).

"Higher set-up costs and higher cost for machinery replacement are the main barriers" (Participant C, Executive)

The first aspects of the barriers discussed in this section pertain to the whole economy of a country, and constitute a type of market failure. They inhibit the implementation of mitigation options indirectly by maintaining conditions in which investments in eco-friendly and green options are ignored, undervalued or considered too risky by economic actors. High tariffs on imported goods or policies that constrain entry of imported enzymes into the local market can 
prevent new and bioprocessing technology from entering the country. Since developing countries often rely on imports for high-efficiency equipment, duties can raise prices considerably. Government regulations that prohibit foreign firms from bidding for the construction of new industrial factories limit a country's access to new foreign technology.

The transfer of modern technology takes place mainly through licensing of designs for local production, joint ventures and export/import. Transnational corporations' practices and country policies can inhibit these modes of technology transfer. Equally, large fluctuations in exchange rates and inflation can inhibit capital flows. The type of enzymes and their processing across developing countries vary with the type of processes and technology which is imported. Countries either import finished or crude enzymes and/or produce insignificant proportion of enzymes in local bioprocessing industries with local strains. The lack of suitable local firms to supply finished enzymes and appropriate technology, limited access to capital and restrictions on repatriation of foreign exchange are some of the conditions that slow the introduction of efficient enzymatic methods.

In addition, it is observed that the dynamics of the introduction of enzyme technology faces difficult economic situations in the textile processing industries. This acts as strong a deterrent for the introduction of enzyme technology as an emerging technology on industrial scale. The processes are very rapid in textile mills but, on the contrary, enzyme operations are relatively slow (reaction time $\sim 30 \mathrm{~min}$ ). This scenario constitutes the major setback for the enzyme produces to invest both time and financial resources to introduce new technology in the industry as this leaves them in a position of no economic gain. In addition, textile processing industries require new production lines set up to replace existing ones for introducing enzyme assisted processes, which involve significant investment, as explained by half of the study participants. Processing usually takes place in well-established industrial settings in which chemical processes are strictly defined and well controlled within the production chain. However, the economic restrictions could be overcome and integration of enzyme technology is possible if the enzymatic processes supersede chemical methods as inexpensive and replacement of technology does not incur any sunk cost. This was well translated by one of our scientist participants: 
"Incorporation of biotechnology in textile and garment industries in developing countries is both an economic, psychological, management capability and formal institutional issue" (Participant A, Scientist).

This implies an expectation that potential technology, to be contemplated by developing country producers, should not require major physical alterations into the infrastructure and provide significant improvement in terms of costs and/or reusability. For the laundries, reduced production costs are not related to adoption of enzyme assisted processes as it requires little expense for adoption of new technology. To encourage rapid take-up of the technology, there is no requirement to establish new production lines and requires no additional machinery. This prevalent view among the participants was summarised by a plant manager:

"Definitely, the production process needs to be modified if we want to integrate enzymatic methods. However, we have the capacity to adapt the system if we're required to do so" (Participant D, General Manager).

Enzyme processes can be easily adopted with the existing industrial setup.

Reluctance to investment is a vital barrier to any innovative practice. In order to achieve the goals of economic and environmental sustainability and building a well-off society, the development of the textile sector in the context of greener and environmental protection will rely on improved process efficiency and production systems incorporating safety and wellbeing of workers. However, as an eminent scientist participant explains:

"The majority of entrepreneurs suffer from myopic vision of enterprise growth based on 'low cost at any expense', while they fail to see the growth of demand for 'green textile and garment' in the premium markets" (Participant A, Scientist).

In general, a large amount of capital is needed to establish new infrastructure and develop efficient systems incorporating enzyme based technology. In addition, the longer investment cycle increases the risk level so that companies of all sizes would rather not pioneer new energy-efficient technologies in their production. Moreover, potential producers of new energy-efficient technologies may not invest in and produce new products without guarantee concerning sales of the new technologies. Hence, it is critical to draw up the relevant policies 
and laws to encourage people to invest in enzyme processing industries and educate entrepreneurs about the benefits of the shift, e.g. not only environmental sustainability but also enhanced company image and long-term return on investment.

Thus, the lack of funding is a key barrier to introduction and adaptation of enzymatic textile processing in the developing countries. Although this type of processing is an efficient way to replace chemical processing and ensuring environmental sustainability, cost considerations are a prime challenge in commercial operation. The high cost has hindered the acceptance and utilization of enzymatic processing, because the technical level of most textile industries in developing countries lags behind developed countries and the scale of the local enzyme manufacturing industry is relatively small and in some cases, there are no industries at all, forcing developers to import enzymes from overseas at a cost around $60 \%-80 \%$ higher than had they been purchased locally. In addition, it costs more to buy efficient process information and technological systems. Besides, a large amount of capital is needed to replace low-quality production system, buy relevant assembly and train skilled work force. In the present condition, finance is essential as well as critical to meet the demand of enzymes, maintain the supply chain and manpower requirements for adaptation of enzyme based processing at the textile industries. Therefore, it becomes impossible to adopt new systems and processes if there is no financing guarantee. This is a key reasons for the shortage of Bangladeshi entrepreneurs in the field, as explained by a participant:

"There lies a big untapped market to produce and commercialise industrial enzymes in Bangladesh, especially in textile and food industries. Unfortunately, there's no biotech industry or entrepreneurs in this area. Every year, Bangladesh imports substantial amounts of enzymes from Europe, China and India" (Participant B, Managing Director).

The lack of incentive support constitutes another critical barrier to shifting to enzymatic practices in textile processing industries. The industries are not willing to adopt enzyme applications because they do not receive direct benefits from it. Under the condition of market mechanism and underdevelopment of relevant technology, it is impossible to win the objectives of society development if only depending on self-regulation. At present, developing countries should encourage the industries to devote themselves to the effective bio-based processing through such methods as tax deduction or exemption, good service, provision of special funding and financial, etc. 


\section{Administrative and institutional barriers}

In textile processing industries, 'conservatism' and risk aversion in management act as potential barriers to the adaptation to textile enzymes in different processing steps. Administrative personnel usually see themselves in no position to estimate the economic margin in full scale production trials. They anticipate the processing to be very expensive and risky if any part of the process goes wrong. Reluctance to take risk was prevalent at both organisational and State levels.

At organisational level, the lack of strategic planning is another remarkable barrier to implementation of enzymatic textile processing. Strategic planning includes the identification of environmental protection goals and the specification of long-term plans for managing the goals. Strategic planning, policy-making, market access, industry supervision and monitoring of environmental standards require more attention to the environmental protection program. Despite the fact that there is increasing pressure on the economy, industry and ecology for more involvement in sustainability, developing country leaders have yet to make environmental protection part of their strategic planning. All the company leaders interviewed expressed this reluctance with some ambivalence. For example, when asked whether they would consider shifting processing techniques, the industry leaders did not offer firm commitment to do so, as apparent in their statements below:

"We're interested in this and need to know more. It's very risky considering tough garments industry in Bangladesh. We need full guarantees about the quality and quantity" (Participant E, Executive Director).

"No garment owners or any other business organisations think in that way" (Participant F, Director).

In the present scenario, due to rapid increases in industrial demand and the environmental deterioration, a sound strategic planning is necessitated for the energy-saving programs. However, the messages and responses from industry leaders, as shown in the statements above, are of significant concerns. 
At State level, government should demonstrate commitment to environmental protection activities to shape strategic organisational goals by integrating all members of the society; yet industry leaders and scientists see little initiatives on the part of the State, as reflected in multiple participant accounts below:

"Weak formal institutional governance structures in developing countries either keep their eyes shut on the powerful industries to make them comply with good environmental practices or incapable of monitoring and enforcing" (Participant A, Scientist).

"From the Bangladesh government viewpoint, we need to monitor the effluent and waste generated in factories. Our factories operate much below the level assigned to by the Ministry of Environment. The Bangladeshi Government is encouraging textile manufacturers to adopt greener textile processing but there's no policy in this regard" (Participant D, General Manager).

To implement bioprocessing/enzyme-assisted processing in any textile industry, the role of strategic planning and that of regulatory bodies are very important to achieve the goals for the countries. Therefore, developing countries should provide continuous support for environmental protection with the strategic plans, action plans.

Inappropriate State industrial framework is therefore a prominent barrier to eco-friendly enzymatic textile wet processing in Bangladesh and most developing countries. In most of these countries, the industrial framework was founded in the period of extreme shortage of resources and production as well as low technological and economic levels. Under such conditions, the industrial framework is mainly comprised of heavy industries, with high consumption and high investment, neglecting environment pollution and energy saving through improving the level of technology. The goal of replacing chemical based processing in the textile industry is hard to achieve without changing the old industrial framework.

Thus, at State level, a chief barrier to adaptation and implementation of enzymatic textile wet processing is the limited policy framework. It is difficult to implement enzymatic processing without support of the relevant policy framework. The practice of enzymatic processing is a complex system, involving many different interested departments, e.g. finance, resources, 
industry, tax, environment, etc., and needs coordination among administrative departments. Presently, there are no sound systems of policymaking and implementation in most developing countries. The Bangladeshi government, for example, insists that:

"We have many factories that are green in terms of compliance. We have strong environmental policies; we're also working towards an integrated policy for production and environmental sustainability" (Participant I, government official).

However, the existing ineffective and fragmented policies or measures fail to meet the need of industrial development and environmental sustainability with the possibility of incorporating enzyme systems (Fang and Zeng, 2007). Hence, it is necessary to establish the policy framework, under which enzymatic textile processing could be either adopted or adapted and developed well. Policy makers are adamant that the government is willing to help as expressed in the words of a key politician interviewed:

“Our government's willing to provide full support where necessary. We have specialised university for textile and many other specialised universities for industrial production. We're capable of adopting any new technology" (Participant I, government official).

Despite the government's promises, many in the business sector and among scientists see only limited funding and national policy framework being put in place.

\section{Training and skills barriers}

Most participants agreed that a major setback for the adoption of enzymatic processing lies in the lack of skills in this technology area. Two industry leaders explained:

"Our processing could be improved by biotechnological techniques and approaches, which are capital and resource-intensive tasks. But skilled manpower, acquisition of cutting edge technology could be limiting factors" (Participant B, Managing Director). 
"Unfortunately, the level of knowledge that I have is very limited. So, we import some critical yarns from abroad [as a result of the lack of skills here]. To my understanding, it's safer for our country" (Participant G, Owner of manufacturing plant).

These concerns signify the urgency of training in enzyme-based technology. The existing manpower should be given continuous training to ensure that up-to-date technology is applied. However, it is not easy to implement raining programmes because of inadequate institutional, financial and technical structures. A substantial number of textile industries do not have staff with scientific and technical knowhow, primarily due to their ignorance of state-of-the art technology and poor academic and technical backgrounds. There is some will to train the personnel, if companies are supported, as two participants explained:

"We're willing to provide training to our employees if we're required to carry out enzymatic processing. We hire consultants and trainers with appropriate skills regularly" (Participant D, General Manager".

"We don't produce and we need foreigners may be" (Participant F, Director).

In the skills context, another serious barrier affecting the adaptation of enzymatic textile processing is the lack of experience in technology and management. Because of the high chemical consumption and low efficient economic development pattern, enzymatic bioprocessing industries are not well-developed; management and administrative personnel do not have enough experience and knowledge about the application and benefits of enzymes in the textile industries. Sometimes, relevant government bodies, such as ministry of industries, science and technology and textiles can act as catalysts for promoting eco-friendly, energy efficient textile processing in many countries. However, there are several problems for these bodies in accessing the market, e.g. lack of funding, information service and professional managers, etc. (Wei, 2004). The issue of capability is well expressed by a scientist and a government official:

"The other probable issue is limited technological and management capability in the enterprise to turn it into a 'green enterprise' through shifting to bio-agent and chemicalbased textile and garment production and manufacturing" (Participant A, Scientist). 
"In my opinion, the technical barriers could be listed as lack of skilled manpower and research personnel" (Participant J, government official).

\section{Informational and sociocultural barriers}

An important barrier to enzyme based textile processing in developing countries is the lack of awareness. Due to substantial economic gains and ample opportunities for income generation and employment, the government is reluctant to propagate information relative to costlier new technologies. Therefore, few policies and laws were enacted. And relevant studies were severely insufficient. Most of companies do not care about environmental issues because of the external costs. The feasibility of the shift to enzyme processing technologies is constrained by social structures and cultural forces. Although some people realise the importance of environmental protection and the effects of corrosive chemicals in existing textile processing industries, they treat the issues with neglect due to the lack of relevant policies and laws. In fact, the implementation of enzymatic textile processing leads not only to direct benefits to the environment but also to economic development in the long run.

Inadequate data and information is a serious barrier faced by developing countries in adopting the process of enzymatic textile processing (OWB and NDRC, 2007). This lack of information is stressed in the narratives of two participants:

"Existence of monopolistic control by the chemical sector and insufficient information about alternative products that are environment friendly are key issues" (Participant $H$, Director for Marketing and Merchandising).

"We don't know much and we are not in a position to do market testing. If other organisations start, we'll follow" (Participant E, Executive Director)

In modern society, data and information have become increasingly important to make decisions. The practice of incorporating enzymatic processing is a complicated technology adaptation process, which needs information and technological support during various stages, 
such as planning, organisation, implementation, evaluation, decision-making, improvement, etc. Unfortunately, the relevant statistics is deficient so that the government and textile industry lack a sound foundation in their planning and forecast. That is to say that the incorporation of enzyme-assisted textile processing cannot meet the expected aims and produce pronounced effects if there is no efficient information system. Thus, an efficient data and information system should be established and access to information needs to be ensured in these setups to deliver the expected outcomes.

\section{FURTHER DISCUSSION: MEASURES FOR OVERCOMING BARRIERS}

It is obvious that enzymatic textile processing technologies which have significant potential to contribute to the development of a country's economy need to be studied in order to identify their barriers and ways to overcome them. As Porter (1986) argues "technological innovations can have important strategic implications for companies and ... greatly influence industries" (p.60). The potential for enzymatic processing in the textile industry could be seen in its technological, techno-economic or economic potential. The technological potential refers to the case (level of usage) where it is assumed that a technically feasible technology is universally used and constraints such as cost, reliability and other attributes that may hinder its application, do not exist. The techno-economic potential refers to the case where it is assumed that a technically feasible and economically viable technology is universally used in a competitive market and constraints such as consumer preferences, social and institutional barriers, financial barriers, etc. to its usage do not exist (Chiarvesio, Marchi and Maria, 2015). Finally, the economic potential refers to the case when a technology (technically feasible and economically viable) was to be used in an environment free from market failures and distortions. The current usage level of the technology can be referred to as market potential, a level attained with existing barriers. Thus, technological potential is the highest order of theoretically possible usage level, followed by techno-economic potential. It may not be possible to achieve technical potential but research and development can reduce the gap between techno-economic potential and technical potential (Dangelico, Pujari and Pontrandolfo, 2017; Dean and Low, 1992). In most cases, the aim is to achieve or move closer to techno-economic potential.

Distortions in the market coupled with unfavourable financial, institutional and regulatory environments (Rahman, Uddin and Lodorfos, 2017; Mendy and Rahman, 2019) imply that 
governmental intervention is imperative to promote greener processing technologies (Goodman, Korsunova and Halme, 2017; Andrews-Speed, 2004). The role of governments in technology transfer has been reported as the key element (IPCC, 2000), which can be applied for the incorporation of enzyme-based technology in the textile industry. This role includes generic actions to remove barriers, building human and institutional capacity, generating research and development infrastructures, creating an enabling environment for investment, and providing information and mechanisms to promote enzymatic technologies.

Policy approaches to achieve the techno-economic potential can either remove the barriers or create conditions where the market is forced to act, ignoring the barriers (Dangelico, 2016; Dean and Low, 1992). The former normally works at the micro level addressing the barriers directly, and the latter mostly at macro level addressing the barriers indirectly. For example, setting up information centres, establishing codes and standards, etc. could address the barriers directly, whereas increasing chemical prices and imposing pollution taxation would address the barriers indirectly. Finally, policy actions need to be designed and implemented to operationalise the measures identified to overcome the barriers.

\section{Liberalisation of industrial policies and enzyme market}

This includes several policy measures such as restructuring enzyme markets, opening up to competition and removing other controls. Some examples of the specific policies are devising environmental regulations for chemical-based processing and promoting markets for industrial biotechnology, allowing private sector entry and diluting or removing controls on higher enzyme prices, enzyme import, and capacity building of government and public research entities, etc. Institutional measures such as setting up independent regulatory bodies may be needed for the success of these policy actions. The fundamental purpose of liberalisation is to increase a country's production and marketing of industrial grade enzymes through facilitating market competition. The initial impact of such measures may be unfavourable to enzyme producers due to increased competition. However, in the long term, a liberalised enzyme market may provide a better environment for the healthy growth of enzymes in industrial processing or bioeconomy.

\section{Economic incentives and Government Initiatives}


Governments need to provide capital subsidies for installation of textile processing production set up at the industry (Fresner et al., 2017; Hassett and Metcalf, 1995). Fresner et al. (2017) found that were government incentives were available to SMEs, these tended to move towards cleaner energy. However the capital subsidies need to have a defined phase out time frame to ensure sustainability of industrial level processing. Tax exemption, credit facilities and third party financing mechanisms are other measures, which could be practiced. Governments should devise national plans and strategies for promotion of industrial uses of enzymes. It should make investments through specialised agencies created for industrial enzyme promotion. There is a need for guaranteed market schemes. Since industrial enzymes for textile processing are not able to compete with chemical processing and their existing markets with existing barriers, textile manufacturers may be required by law to incorporate enzymes in some or most of their processing steps (see Alam, Selvanathan and Selvanathan, 2017; Mostafa and Klepper, 2017).

Informative programmes need to be launched to promote enzyme based processing over chemical processing at industry. The stakeholders can be educated and supplied with the necessary tools to evaluate enzymatic processing and design implementation (Mostafa and Klepper, 2017; Murillo-Luna, Garcés-Ayerbe and Rivera-Torres, 2011). The campaigns are both general in nature and targeting specific enzyme-based processing promotion over chemicals. Since high expense is a major barrier to enzyme market penetration and intervention in the textile industry over chemical based processing, $R \& D$ programmes should be set up to make it more competitive and attractive in application. Long-term adoption of enzymatic technology costs can be reduced through research

\section{Institutional measures, standards and regulations}

Governments need to set up specialised agencies for planning and promotion of enzyme production, marketing and uses. Regulatory agencies need to be established to foresee whether liberalisation of the enzyme market takes place. Other measures could include promotion of service companies which would address several barriers, e.g. lack of up-front financing, credit facilities, and technical knowledge (Fresner et al., 2017; Goodman, Korsunova and Halme, 2017; Greer et al., 2015; Hassett and Metcalf, 1995). Several facilitating measures could be undertaken by governments. These usually include financing for feasibility studies, planning and fixing targets for achieving enzyme based processing, resource assessment for enzyme production and application at national and regional levels,, technology demonstrations etc. 
Skill development through training in various aspects of adaptation for the technology (e.g. technical, regulatory, managerial, financial skills etc.) could be arranged by government entities and facilitated by nongovernment organisations.

\section{CONCLUSION AND IMPLICATIONS}

\section{Conclusions}

To some extent, fashion dictates manufacturing of new clothes with new properties and qualities and there is an increasing trend of market demand in this regard. Various enzymatic processes in the textile industry improves the quality of the products and in many instances, they might replace chemical processing during production. In case of enzyme based processing for the operation in laundries, the complexity of translation pricing can be daunting. It sometimes becomes quite uncertain whether the products worth higher prices because of complex market pricing mechanisms with regards to finished products. However, with regards to enzymatic processing in the textile mills, opposite scenario prevails where somewhat simple association between quality and price exists. Given the nature of the demand driven aspect in textile mill processing, the textile mills could incur extra production costs for a certain product (e.g. 'ecofriendly') with higher price according to purchasing requisition by a buyer. However, in the current conditions, producer sides are unwilling to take any risk because environmental friendliness does not 'sell' in itself for a given product (Melander, 2018).

There is a lack of coordination between enzyme manufacturing industries and textile processing industries. Enzyme producers are well informed and supportive toward biotechnological applications of laundry segment in textile processing, but they are reluctant to conduct trails to evaluate the effectiveness of enzymatic systems by themselves. The strong economies of scale create barriers to entry and are connected to difficulties for the assessment of the long-term benefits and subsequent average production costs. However, the increasing trend is that the global textile industry is shifting towards unique and high-tech products with need for industrial and environmental sustainability.

The adoption of enzymes in textile processing is largely influenced by the level of manufacturers' responsiveness and the surrounding community against safety awareness level and the concern in managing the environmental issues. Besides, increased public environmental awareness has urged manufacturers to adopt the best practices in managing the environmental concern. This subsequently increases manufacturers' proactiveness in moving towards textile enzyme processing, primarily responding to increasing pressure that results from enforceable environmental regulations (Tseng et al. 2009). Besides, the ability to adopt 
enzymes in textile processing depends on the continual knowledge in managing the demand and supply of material and resources in the supply chain (Moors et al., 2005; Yusup et al., 2013). The implementation of enzymes in textile processing, particularly through green supply chain, has encouraged the business partners in the supply chain to actively implement better environmental management practices, e.g. enzymatic processing. This subsequently allows the manufacturer increases the environmental awareness level that has a potential to increase the success rate in the implementation of enzymes in textile processing. Conversely, the limited knowledge as well as the slow development particularly in establishing a green supply chain evidently seen able to obstruct the successful implementation of enzymes in textile processing (Murillo-Luna et al., 2011). Moreover, the adoption level of enzymes in textile processing has a significant positive relationship with business performance (Zeng et al., 2010). The manufacturer's ability to produce environmentally friendly products that in line with the highest environmental management practice level absolutely able to increase the performance and the reputation of the manufacturer in the global market particularly in handling the environmental issues that occur. This has proved that the successful implementation of enzymes in textile processing seen able to increase the ability of manufacturers in managing the resources in manufacturing activity as well as industrial waste management at a more efficient level particularly in reducing the risk of hazard against human safety and health and environmental (Zwetsloot, 1995; Tseng et al., 2009). Therefore, the focus and intention to fulfill this requirement was a basis for the implementation of enzymes in textile processing. The ability to fulfill all the established policies and standards in environmental management had encouraged manufacturers to comply with the laws and regulations. This shows that the establishment of the corporate policies and environmental mission statements is important in achieving an efficient enzymes based textile processing (Montabon et al. 2007). The ability to adopt these regulations and fulfil the corporate policies, and the environment mission statements is not just beneficial in managing arising environmental issues, but also increases the ability of manufacturers to provide a better working environment.

\section{Implications}

The transformation in improving economic growth through pollution prevention and the streamlining in industrial waste management is seen to influence the implementation of enzymatic practices (Peng and Li, 2011). Additionally, the high enforcement level seen as the main input for manufacturer to begin to adapt enzymatic practice particularly in managing environmental issues. Besides the possible high investment required in conventional 
environmental management, e.g. EOP, and high expectation of return on investment are seen as the critical elements that strongly influence the decisions of the manufacturer in implementing enzymatic practices (Guo et al. 2006). The change of behaviour in adopting enzymatic processing can strengthen operational efficiency, reduce the non-product output, improve performance, reputation and eventually provide a good return in profit (Altham, 2007; Wan Mahmood et al. 2012). Besides, awareness of the constraints of resources and material necessitates the manufacturer to reduce their manufacturing cost and increase financial performance. This could be realised via an efficient resources utilization and reduction of pollution and industrial waste generated (Huang et al. 2013). The savings obtained from the reduction of manufacturing costs primarily in handling the pollution and industrial waste would allow the manufacturer to increase the budget and investments in the utilization of the new enzyme-based processing technology. In addition, this capacity would reduce the overall manufacturing cost and subsequently increase the manufacturing efficiency. This situation would eventually enhance the efficiency of manufacturing activity and increase the manufacturing sustainability performance.

\section{REFERENCES}

Aghion, P. and Howitt, P., 1998: Endogenous Growth Theory. MIT Press, Cambridge, MA. Alam, M.S., Selvanathan, E. A., and Selvanathan, S., 2017: Determinants of the Bangladesh garment exports in the post-MFA environment. Journal of the Asia Pacific Economy, 22(2), $330-352$.

Altham, W., 2007: Benchmarking to Trigger Cleaner Production in Small Businesses: Drycleaning Case Study. Journal of Cleaner Production. 15, 798-813.

Anastas, P.T. and Warner, J.C. 1998: Green chemistry: theory and practice. Oxford University Press, Oxford (England), New York. ISBN 9780198502340

Andrews-Speed, P., 2004: Energy policy and regulation in the People's Republic of China. The Hague: Kluwer Law International.

Chiarvesio, M., Marchi, V.D., and Maria, E.D., 2015: Environmental innovations and internationalization: Theory and practices. Business strategy and the environment, 24(8), 790801. 
Dangelico, R.M., 2016: Green product innovation: where we are and where we are going. Business Strategy and the Environment, 25(8), 560-576.

Dangelico, R.M., Pujari, D. and Pontrandolfo, P., 2017: Green product innovation in manufacturing firms: A sustainability-oriented dynamic capability perspective. Business Strategy and the Environment, 26(4), 490-506.

Dean, J. and P. Low, 1992: Trade and the Environment: A Survey of the Literature. International Trade and the Environment. World Bank Discussion Paper 159.

Development and Human Security, February 13-14, Tokyo. http://coe21policy.scf.keio.ac.jp/ja/event/.le/s2-6.pdf.

Fang, Y. and Zeng, Y., 2007: Balancing energy and environment: the effect and perspective of management instruments in China. Energy.

Fresner, J. et al., 2017: Energy efficiency in small and medium enterprises: Lessons learned from 280 energy audits across Europe. Journal of Cleaner Production, 142, 1650-1660.

Goodman, J., Korsunova, A. and Halme, M., 2017: Our collaborative future: Activities and roles of stakeholders in sustainability-oriented innovation. Business Strategy and the Environment, 26(6), 731-753.

Greer, L. et al., 2015: The textile industry leaps forward with Clean by Design: Less Environmental Impact with Bigger Profits, Natural Resources Defense Council (NRDC)

Guo, H.C. et al., 2006: Assessment of Cleaner Production Options for Alcohol Industry of China: A Study in the Shouguang Alcohol Factory. Journal of Cleaner Production. 14, 94103.

Hassett, K.A., and Metcalf, G.E., 1993: Energy Conservation Investment: Do Consumers Discount the Future Correctly? Energy Policy, 21(6), 710-716.

Hassett, K.A., and Metcalf, G.E., 1995: Energy Tax Credits and Residential Conservation Investment: Evidence From Panel Data. Journal of Public Economics, 57, 201-217.

Huang, Y., Luo, J. and Xia. B., 2013: Application of Cleaner Production as an Important Sustainable Strategy in the Ceramic Tile Plant-A Case Study in Guangzhou, China. Journal of Cleaner Production. 43, 113-121.

Hofmann, K.H., Theyel, G., and Wood, C.H., 2012: Identifying firm capabilities as drivers of environmental management and sustainability practices-evidence from small and mediumsised manufacturers. Business Strategy and the Environment, 21(8), 530-545.

IPCC, 2000: Methodological and technological issues in technology transfer. In: Metz B, Davidson O,

Jovanovic, B., and Y. Nyarko, 1994: The Bayesian Foundations of Learning by Doing. NBER WP 4739. 
Krusell, P., and J.V. Ríos-Rull, 1996: Vested Interests in a Positive Theory of Stagnation and Growth. Review of Economic Studies, 63, 301-329.

Melander, L., 2018: Customer and supplier collaboration in green product innovation: External and internal capabilities. Business Strategy and the Environment, 27(6), 677-693.

Mendy, J. and Rahman, M., 2019: Application of HRM's Universal Model: an examination of people vs institutions as barriers of internationalization for SMEs in a small developing country. Thunderbird International Business Review. 61 (2), 363-374.

Montabon, F., Sroufe, R. and Narasimhan. R., 2007: An Examination of Corporate Reporting, Environmental Management Practices and Firm Performance. Journal of Operations Management. 25(5), 998-1014.

Moors, E.H.M., Mulder, K.F. and Vergragt, P.J., 2005: Towards Cleaner Production: Barriers and Strategies in the Base Metals Producing Industry. Journal of Cleaner Production. 13(7), $657-668$.

Mostafa, R. and Klepper, S., 2017: Industrial development through tacit knowledge seeding: Evidence from the Bangladesh garment industry. Management Science, 64(2), 613-632.

Murillo-Luna, J.L., Garcés-Ayerbe, C. and. Rivera-Torres. P., 2011: Barriers to the Adoption of Proactive Environmental Strategies. Journal of Cleaner Production. 19(13), 1417-1425.

Olson, M., 1982: The Rise and Decline of Nations: Economic Growth, Stagflation, and Social Rigidities. Yale University Press.

Organisation of World Bank (OWB), Centre of economic Development of National Development and Reform Commission of China (NDRC), 2007: China: Energy sustainability: the closing window of opportunity, vol. 164. The Development Publication of China, Beijing, pp.8-9 panel on climate change. Cambridge University Press.

Peng, L. et al., 2015: Analysis of energy efficiency and carbon dioxide reduction in the Chinese pulp and paper industry. Energy Policy, 80, 65-75.

Peng, W. and Li., C., 2011: Cleaner Production Evaluation in Aviation Industry based on AHPFuzzy. 2011 2nd International Conference on Artificial Intelligence, Management Science and Electronic Commerce (AIMSEC). 3820-3823.

Porter, M.E., 1986: Technology and competitive advantage. Journal of Business Strategy 5(3) 60-78.

Rahman, M., Uddin, M. and Lodorfos, G., 2017: Barriers to enter in foreign markets: evidence from SMEs in emerging market. International Marketing Review. 34(1): 68-86. 
Senthil Kumar, P. and Gunasundari, E., 2018: Sustainable Wet Processing-An Alternative Source for Detoxifying Supply Chain in Textiles. In: Muthu, S., (eds) Detox Fashion. Textile Science and Clothing Technology. Springer, Singapore.

Shrum, L.J., Lowrey, T.M. and McCarty, J.A., 2008: Recycling as a marketing problem: A framework for strategy development. Psychology and Marketing 11(4) 393-416D.O.I: https://doi.org/10.1002/mar.4220110407|

Tseng, M.L., Lin, Y.H. and Chiu, A.S.F., 2009: Fuzzy AHP-based study of Cleaner Production Implementation in Taiwan PWB Manufacturer. Journal of Cleaner Production. 17(14), 12491256.

Van Beers and J. Van den Bergh, 1997: An Empirical Multi-Country Analysisof the Impact of Environmental Regulations on foreign Trade Flows. Kyklos, 50, 29-46.

Wan Mahmood, W.H., Ab Rahman, M.N. and Md Deros. B., 2012: Green Supply Chain Management in Malaysian Aero Composite Industry. Jurnal Teknologi ISSN 0127-9696. 59, $13-17$.

Wei, Z.H., 2004: Economic development and energy issues in China. Working paper prepared for the First KEIO-UNU-JFIR Panel Meeting, The 21 st Century Center of Excellence Program, Economic.

WTO, 2018: World trade statistical review. Geneva: World Trade Organisation.

Yusup, et al., 2013: The Translational Process of Cleaner Production Strategies. Global Engineers and Technologists Review. 3(5), 29-39.

Zeng, S. X. et al., 2010: Impact of Cleaner Production on Business Performance. Journal of Cleaner Production. 18(10-11), 975-983.

Zuberi, M. J.S., Tijdink, A. and Patel, M.K., 2017: Techno-economic analysis of energy efficiency improvement in electric motor driven systems in Swiss industry. Applied energy, 205, 85-104.

Zwetsloot, G.I.J.M., 1995: Improving Cleaner Production by Integration into the Management of Quality, Environment and Working Conditions. Journal of Cleaner Production. 3(1), 6166. 